\title{
Taxcor for the prevention of restenosis. Polish multicentre observational study to assess the efficacy and safety of the Genius TAXCOR I stent
}

Taxcor w zapobieganiu restenozie. Polskie wieloośrodkowe badanie obserwacyjne oceniające skuteczność i bezpieczeństwo stentu Genius TAXCOR I

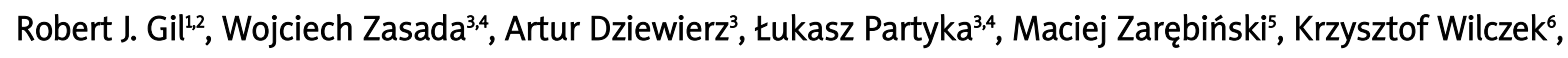 \\ Dariusz Dudek, Paweł Buszman', Maciej Lesiak ${ }^{8}$, Witold Rużyłło \\ 1Department of Interventional Cardiology, Central Clinical Hospital of the Ministry of the Interior and Administration, Warsaw, Poland \\ 2Medical Research Centre of The Polish Academy of Sciences, Warsaw, Poland \\ ${ }^{3} 2^{\text {nd }}$ Department of Cardiology, Krakow University Hospital, Poland \\ 4Krakow Cardiovascular Research Institute, Poland \\ ${ }^{5}$ Military Institute of Medicine, Warsaw, Poland \\ ${ }^{6}$ Silesian Centre for Heart Diseases, Zabrze, Poland \\ 7Polish-American Heart Clinics, Ustron, Poland \\ $81^{\text {st }}$ Department of Cardiology, Poznan Medical University of Science, Poland \\ ${ }^{9}$ Department of Coronary Artery Disease and Structural Heart Diseases, Institute of Cardiology, Warsaw, Poland
}

Post Kardiol Interw 2011; 7, 4 (26): 285-291

DOI: $10.5114 /$ pwki.2011.25786

\begin{abstract}
Background: The Taxcor PL registry was a multicentre, phase IV open clinical trial, in which there participated 10 academic centres in Poland. Its aim was to assess the safety and effectiveness of the stent Genius TAXCOR I (Eurocor GmbH, Germany) at a dose of $1 \mu \mathrm{g} / \mathrm{mm}^{2}$ of paclitaxel, implanted during PCl with elective or urgent indications.

Material and methods: Patients who entered the study were a group of patients qualified for $\mathrm{PCl}$, based on clinical symptoms and provocative tests, in whom coronary angiography confirmed the presence of significant stenosis (length up to $25 \mathrm{~mm}$ ) in the coronary arteries. Implantation procedure, peri- and postoperative procedure were in accordance with guidelines and local practice. The study protocol did not interfere with standard treatment for patients with a diagnosis of ischaemic heart disease. The total number of patients studied in the Taxcor PL registry is 100 people recruited in 10 centres in Poland.

Results: Data were collected during the study on $100 \mathrm{PCls}$ (110 treated lesions). Average duration of PCI was 43 min (SD 24). Mean diameter of the implanted stent was $3.17 \mathrm{~mm}$ (SD 0.36) and the average length of $20.5 \mathrm{~mm}$ (SD 5.82). The mean time of hospitalization of patients enrolled in the study was 2.5 days (SD 3.4). During hospitalization, 2 patients experienced myocardial infarction which was the result of side branch closure during PCI. Three patients had a haematoma at the puncture site, which did not require surgical intervention and transfusion of blood products. During percutaneous coronary intervention also three cases of distal dissection were reported (type B, C and D). There were no other adverse events. In one-month follow-up one of the patients had a planned $\mathrm{PCl}$ procedure performed in another vessel than previously treated, which was the next stage of coronary revascularization. Similarly, in the 3-month follow-up one of the patients needed to undergo a $\mathrm{PCl}$ procedure on a vessel untreated with Taxcor. In the 6-month follow-up (3-6 months) one patient died - he was hospitalized with a diagnosis of malignant tumour and the gastrointestinal tract and operated on at the surgical ward (hemicolectomy); after 2 months of hospitalization, he died due to multiorgan failure. Five patients had a second percutaneous coronary intervention in other vessels than at the time of study enrolment. At 12-month follow-up (6-12 months) two patients had a second PCI procedure performed, including one in a vessel treated at the time of enrolment. Ineffectiveness of supply target vessel (called target vessel failure, TVF) occurred in three patients (death from coronary causes $-0, \mathrm{MI}-2$, target vessel revascularization (TVR $-\mathrm{PCI}$ or CABG) during the 12-month observation period - 1 .
\end{abstract}

Corresponding author/Adres do korespondencji:

Robert J. Gil MD, PhD, Department of Interventional Cardiology, Central Clinical Hospital of the Ministry of the Interior and Administration, 137 Wołoska, 02-507 Warsaw, Poland, tel.: +48 608457 757, e-mail: robert.gil@cskmswia.pl

Praca wpłynęła: 13.09.2011, przyjęta do druku: 28.10.2011. 
Conclusions: Taxcor PL registry results showed that the stent Genius Taxcor I is safe to use and provides satisfactory results in short- and long-term observation, in comparison with other commercially available coronary stent systems.

Key words: paclitaxel-eluting stent, restenosis

\section{Streszczenie}

Wprowadzenie: Rejestr Taxcor PL był wieloośrodkowym, otwartym badaniem klinicznym fazy IV, w którym uczestniczyło 10 ośrodków akademickich w Polsce. Jego celem była ocena bezpieczeństwa i skuteczności stentu Genius TAXCOR I (Eurocor GmbH, Germany) uwalniającego paklitaksel w dawce $1 \mu \mathrm{g} / \mathrm{mm}^{2}$, implantowanego podczas przezskórnej angioplastyki wieńcowej (ang. percutaneous coronary intervention, $\mathrm{PCl}$ ) ze wskazań planowych lub nagłych.

Materiał i metody: Pacjenci włączani do badania stanowili grupę chorych kwalifikowanych do zabiegu PCI na podstawie dolegliwości klinicznych, wyników testów prowokacyjnych, u których w wykonanej angiografii tętnic wieńcowych potwierdzono obecność istotnego zwężenia (długość do $25 \mathrm{~mm}$ ) w zakresie tętnic wieńcowych. Procedura implantacji stentu i postępowanie okołoi pozabiegowe były zgodne z obowiązującymi wytycznymi oraz lokalną praktyką ośrodków. Protokół badania nie ingerował w standardy leczenia pacjentów z rozpoznaniem choroby niedokrwiennej serca. Łączna liczba pacjentów analizowanych w rejestrze Taxcor PL wynosiła 100 osób zrekrutowanych w 10 ośrodkach w Polsce.

Wyniki: Dane zgromadzone w trakcie badania dotyczą 100 zabiegów PCI w zakresie 110 leczonych zmian. Średni czas trwania zabiegu PCI wyniósł 43 min (SD 24), średnia średnica implantowanych stentów wyniosła 3,17 mm (SD 0,36), a średnia długość 20,5 mm (SD 5,82). Średni czas hospitalizacji pacjentów włączonych do badania to 2,5 doby (SD 3,4). W trakcie hospitalizacji u 2 pacjentów doszło do zamknięcia bocznicy podczas zabiegu PCl, czego następstwem był zawał mięśnia sercowego. U 3 pacjentów wystąpił krwiak w miejscu wkłucia, niewymagający interwencji chirurgicznej oraz przetoczenia preparatów krwi. W trakcie zabiegu PCl raportowano ponadto 3 przypadki dystalnej dysekcji (typu B, C i D). Poza tym nie obserwowano innych zdarzeń niepożądanych. W obserwacji 1-miesięcznej 1 pacjent miał wykonany planowy zabieg PCI w zakresie innego naczynia niż wcześniej leczone, będący kolejnym etapem rewaskularyzacji wieńcowej. Podobnie w obserwacji 3-miesięcznej u 1 z chorych wynikła konieczność wykonania zabiegu PCI na naczyniu nieleczonym implantacją stentu Taxcor. W 6-miesięcznej obserwacji (3.-6. miesiąc) zmarł 1 pacjent - był on hospitalizowany i operowany na oddziale chirurgicznym (hemikolektomia) z rozpoznaniem złośliwego guza przewodu pokarmowego i po 2 miesiącach zmarł z powodu niewydolności wielonarządowej. Pięciu pacjentów miało wykonany powtórny zabieg PCI w zakresie innych naczyń niż w momencie włączenia do badania. W 12-miesięcznej obserwacji (6.-12. miesiąc) 2 pacjentów miało wykonany powtórny zabieg PCl, w tym 1 w naczyniu leczonym w momencie włączenia do badania. Nieskuteczność zaopatrzenia naczynia docelowego (ang. target vessel failure, TVF) wystąpiła u 3 pacjentów [zgon z przyczyn wieńcowych - 0, zawał serca - 2, rewaskularyzacja zaopatrywanego naczynia (ponowna angioplastyka lub wszczepienie zespoleń omijających w zakresie zaopatrywanego naczynia) w ciągu 12-miesięcznego okresu obserwacji - 1].

Wnioski: Wyniki rejestru Taxcor PL dowodzą, że stent Genius Taxcor I jest bezpieczny w użyciu i zapewnia uzyskanie zadowalających wyników w obserwacji krótko- i długoterminowej, porównywalnych z innymi dostępnymi na rynku systemami stentów wieńcowych.

Słowa kluczowe: stent uwalniający paklitaksel, restenoza

\section{Introduction}

Percutaneous coronary intervention $(\mathrm{PCl})$ is a routine method of treatment used to restore normal blood flow through the coronary arteries in patients with ischaemic heart disease. Main factors limiting the effectiveness of this method include restenosis and in-stent thrombosis. Introduction of the antiproliferative drug-eluting stents (drug-eluting stents, DES) reduced, but did not eliminate the restenosis phenomenon. The symptoms of recurrent stenosis or coronary artery occlusion typically occur 6-9 months after $\mathrm{PCl}$. The frequency of restenosis is $20-50 \%$ and it depends on the number of clinical risk factors and specific characteristics of the atherosclerotic lesion [1]. Various substances were assessed clinically for their ability to reduce restenosis. Only in the case of DES has there been a reduction of the restenosis risk by over $75 \%$ in comparison to the uncoated, bare-metal stents [2]. Stents have been covered with immunosuppressive drugs (sirolimus and its analogues, tacrolimus), cell proliferation inhibitors (sirolimus, paclitaxel, actinomycin), anti-inflam- matory drugs (dexamethasone), extracellular matrix modulators (batimastat) or endothelium regenerating drugs (17 $\beta$-oestradiol). Described drugs are frequently combined with synthetic polymers acting as reservoirs releasing the drug over a period of several weeks or months. The problem of in-stent thrombosis in patients with implanted bare-metal stent (BMS) was initially reduced by the introduction of dual antiplatelet therapy. It returned in the form of a more frequent late in-stent thrombosis caused by more widespread use of DES. This phenomenon regards antiproliferative drug-eluting stents and is probably related to slower endothelialization and therefore to a longer period of contact between the circulating blood and the stent uncoated by endothelium. The first studies comparing the safety profile of BMS and DES demonstrated a higher risk of in-stent thrombosis in DES [3]. Since then the introduction of new technologies of DES production and new drugs used for stent coating have led to a better and better safety profile [4] and a significant reduction of the frequency of in-stent thrombosis. In view of many advantages of DES in 
comparison to other therapeutic options in ischaemic heart disease constant refinement of these stents seems an important issue. It leads to an increase of safety and efficacy of treatment and justifies efforts to find new technologies and to test their effectiveness in clinical studies. The use of DES has advantages over systemic drug administration. Local action of the drug released from a stent yields higher local concentration of the active compound and their precise release during a requested time. With this route of administration the systemic effect is minimal and usually free from toxicity. Drugs released from stents belong to the group of immunosuppressive and cytostatic substances characterized by specific pharmacokinesis and clinical action.

\section{Aim}

The aim of the study was to assess the safety and efficacy of the Genius TAXCOR I stent (Eurocor $\mathrm{GmbH}$, Germany) eluting $1 \mathrm{\mu g} / \mathrm{mm}^{2}$ of paclitaxel implanted during elective or emergency $\mathrm{PCl}$.

The procedure of stent implantation had to conform with current clinical practice and standards of care of the participating centre.

\section{Material and methods}

\section{Study plan}

Taxcor PL registry was a multicentre, open-label phase IV clinical trial. The registry was conducted in 10 university centres in Poland.

Collected data included information on $\mathrm{PCl}$ procedures and laboratory results of the studied patients. According to the protocol all patients were obliged to report data regarding their health status during a telephone contact with the attending physician (after 1, 3 and 6 months of observation) and to return for examinations after 12 months of observation. The study included 102 patients. Two patients were excluded from the final analysis due to large proportion of missing data.

All data were collected with the use of electronic case report forms (e-CRF) accessed online (ww.taxcor.pl). Each investigator had a personal authentication login and password, the connection was secured with SSL protocol and the system met the standards required for EDC devices.

\section{Studied population}

The study included consecutive patients meeting clinical and angiographic criteria of the Genius TAXCOR I stent use and qualified for percutaneous coronary intervention. The main inclusion criterion was the presence of angina or other obvious signs of myocardial ischaemia and patient's eligibility for $\mathrm{PCl}$ or coronary artery bypass grafting (CABG). Therefore the group included in the study consisted of patients qualified for $\mathrm{PCl}$ based on the clinical symptoms and/or results of the stress tests in whom coronary angio- graphy confirmed the presence of significant coronary artery stenosis. Angiographic inclusion criteria were: de novo stenosis or restenosis of the coronary artery with lumen reduction over $70 \%$ (assessed according to the centre defined protocols - visually or with the use of quantitative coronary angiography (QCA)) and with angiographically confirmed diameter $>2.25 \mathrm{~mm}$ and $<4.0 \mathrm{~mm}$ (appropriate to the available stent sizes). The length of stenosis could not exceed $25 \mathrm{~mm}$; it was important to cover the whole stenosis with a stent. In case of the need to place several stents (for example due to edge dissection, displacement of the stent during implantation or miscalculation of the stent length) they had to overlap. Only two stenoses could be treated during one $\mathrm{PCl}$ procedure, but they had to be located in two different coronary arteries (left anterior descending of the left coronary artery (LAD) or circumflex artery of the left coronary artery (Cx) or right coronary artery (RCA)).

Before initiation of any study procedures patients included in the study had to sign an informed consent form. The study received approval from the Bioethical Committee (Committee for Ethics and Supervision of Studies on Humans and Animals of the Central Clinical Hospital of the Ministry of Interior and Administration in Warsaw).

A full list of the inclusion and exclusion criteria is presented in Table 1.

Stent implantation procedure.

Peri- and post-procedural treatment

The stent implantation procedure as well as peri- and post-procedural treatment conformed with the current guidelines and with the local practice of the centre. The study protocol did not interfere with the standards of care in patients with ischaemic heart disease.

\section{Follow-up period and study end-points}

Data were collected using an electronic CRF. According to the protocol a telephone contact with the patient was required after 1, 3 and 6 months of follow-up. There was also a control visit with the attending physician after 12 months of follow-up which included collection of data on the incidents considered as MACE, classification of the angina symptoms and ascertainment of compliance to prescribed pharmacotherapy.

\section{Study end-points}

The primary end-point of the study was a target vessel failure (TVF) defined as coronary death, myocardial infarction (ST-segment elevation myocardial infarction (STEMI) and non-ST-segment elevation myocardial infarction (NSTEMI)) or target vessel revascularization (repeated $\mathrm{PCl}$ or surgery with bypasses of the stented vessel) during 12 months of follow-up. In case of inability in assignment of death or myocardial infarction to the treated vessel these incidents were considered as such. 
Table 1. Study inclusion/exclusion criteria

Tabela 1. Kryteria włączenia lub wyłączenia z badania

\begin{tabular}{|c|c|}
\hline Inclusion criteria & Exclusion criteria \\
\hline \multirow{2}{*}{$\begin{array}{l}\text { - Age } \geq 18 \text { years } \\
\text { - Negative result of the pregnancy test in women in the procreational } \\
\text { period performed during } 7 \text { days before inclusion and the use of an } \\
\text { effective contraception methods for } 8 \text { months after the procedure }\end{array}$} & - Any predictable situation of antiplatelet drug administration for \\
\hline & $\begin{array}{l}\text { less then } 6 \text { months (planned non-cardiac surgery, drug intolerance) } \\
\text { - The need for treatment of more than two stenoses in the same } \\
\text { vessel }\end{array}$ \\
\hline \multirow{4}{*}{$\begin{array}{l}\text { - Planned treatment of maximally two de novo stenoses and/or } \\
\text { restenoses (only after balloon angioplasty, in-stent restenosis is } \\
\text { the exclusion criterion) in different main coronary arteries } \\
\text { (LAD, RCA, Cx) or in their main branches eligible for PCl } \\
\text { and stent implantation }\end{array}$} & • Total vessel occlusion \\
\hline & $\begin{array}{l}\text { - Stenosis containing vessel bifurcation requiring implantation } \\
\text { of a ramified stent (two stents) }\end{array}$ \\
\hline & - Calcified stenosis excluding the possibility of dilation \\
\hline & $\begin{array}{l}\text { - Very tortuous coronary vessel excluding the possibility of stent } \\
\text { introduction }\end{array}$ \\
\hline - Stenosis length $<25 \mathrm{~mm}$ by visual assessment & - In-stent restenosis \\
\hline - Vessel stenosis $>70 \%$ by visual assessment & - Intracoronary brachytherapy during previous 6 months \\
\hline \multirow{10}{*}{$\begin{array}{l}\text { - Sign informed consent form before initiation of the study } \\
\text { procedures }\end{array}$} & - Stenosis of the saphenous vein graft \\
\hline & - Stenosis of the internal thoracic artery bypass \\
\hline & - Unprotected left main coronary artery stenosis $\geq 50 \%$ \\
\hline & $\begin{array}{l}\text { - Acute or chronic renal failure (plasma creatinine concentration } \\
>2 \mathrm{mg} \% \text { ) }\end{array}$ \\
\hline & - Left ventricular ejection fraction (LVEF) $<35 \%$ \\
\hline & - Cardiogenic shock \\
\hline & - Acute infectious disease \\
\hline & - Predicted life expectancy below 1 year \\
\hline & $\begin{array}{l}\text { - Any clinical situation which in the physician's opinion may } \\
\text { interfere with participation in the study }\end{array}$ \\
\hline & $\begin{array}{l}\text { - Participation in another clinical trial in which end-points have not } \\
\text { yet been met or which can influence the final results of the study }\end{array}$ \\
\hline
\end{tabular}

Secondary end-points of the study included:

- MACE (major adverse cardiac event) incidents defined as death, myocardial infarction (STEMI, NSTEMI), target vessel revascularization during 30 days and 12 months of follow-up;

-1-month and 12-month mortality;

-1-month and 12-month coronary mortality, classified as such in dubious cases;

- 1-month and 12-month myocardial infarction defined as pathological ST-segment elevation with increase of CK-MB above the upper reference limit (STEMI) or lack of ST-segment elevation with increase of CK-MB above the upper reference limit (NSTEMI); at least 5-fold increase of CK-MB above the upper reference limit was necessary to diagnose myocardial infarction related to CABG, and at least 2-fold increase of CK-MB above the upper reference limit was necessary to diagnose a periprocedural myocardial infarction (related to $\mathrm{PCl}$ );

- target lesion revascularization (TLR) defined as any revascularization of the stented vessel segment $\pm 5 \mathrm{~mm}$ proximally or distally to the stented segment during 1-month and 12-months follow-up;

- target vessel revascularization (TVR) defined as any revascularization of the treated vessel during 1-month and 12-months follow-up;

- in-stent thrombosis during 1-month (early) and 12-month (late) follow-up defined as an acute coronary syndrome with angiographically documented vessel occlusion caused by thrombus located in the proximity of the previously implanted stent or any myocardial infarction or coronary death related to the treated vessel in case of lack of angiographic confirmation;

- success of the studied device defined as achievement of final stenosis diameter $<30 \%$ assessed by a physician performing $\mathrm{PCl}$;

- successful procedure defined as achievement of final stenosis diameter $<30 \%$ without MACE related to the treated lesion during hospitalization.

\section{Statistical analysis}

Because of the observational character of the study, no formal study sample calculation was performed. Descriptive statistics were presented for all analysed variables including division into pre-defined subgroups. In the case of nonparametric variables data were presented as numbers and percentages. Continuous variables were presented as mean, standard deviation, median, minimum, maximum and the number of observations.

\section{Results}

The total number of patients analysed in the Taxcor PL registry was 100 recruited in 10 centres in Poland. Baseline demographic and clinical data of the studied patients are presented in Table 2. 


\section{Percutaneous coronary interventions - detailed data}

Analysis of the studied group demonstrated that in $90 \%$ of cases $\mathrm{PCl}$ involved one coronary artery with one critical stenosis. Localization of the treated lesions is presented in the Table 3.

Data obtained during the study include $100 \mathrm{PCl}$ procedures involving 110 atherosclerotic lesions. The mean time of the $\mathrm{PCl}$ procedure was $43 \mathrm{~min}$ (SD 24). The mean diameter of the implanted stent was $3.17 \mathrm{~mm}$ (SD 0.36) and its mean diameter was $20.5 \mathrm{~mm}$ (SD 5.82). Characteristics of the treated lesions by visual assessment of the operator are presented in Table 4.

Ten patients received a $600 \mathrm{mg}$ loading dose of clopidogrel before the procedure, 6 patients received a $300 \mathrm{mg}$ loading dose and 56 patients were on chronic clopidogrel treatment before the procedure and did not require a loading dose. Mean dose of unfractionated

Table 2. Demographic and clinical data of the studied patients

Tabela 2. Dane demograficzne i kliniczne badanych pacjentów

\begin{tabular}{lc} 
Baseline demographic data & $\begin{array}{c}\text { Value (percentage) } \\
\text { or } \pm \text { SD }\end{array}$ \\
\hline Number of patients & 100 \\
\hline Age [years] & $63.8 \pm 8.9$ \\
\hline Women & $34(34 \%)$ \\
\hline Men & $66(66 \%)$ \\
\hline History of diabetes/insulin use & $27 / 100(27 \%) / 8$ \\
\hline History of myocardial infarction & $99(50.5 \%)$ \\
\hline Hypertension & $83(83 \%)$ \\
\hline Current cigarette smoker & $98(20.4 \%)$ \\
\hline Peripheral arterial disease & $92(7.6 \%)$ \\
\hline Dyslipidaemia & $86(86 \%)$ \\
\hline History of PCl & $44(44 \%)$ \\
\hline History of coronary artery bypass & $3(3 \%)$ \\
grafting (CABG) & \\
\hline Baseline clinical data & Value (percentage) \\
\hline or \pm SD \\
\hline Stable coronary artery disease & $85 / 100(85 \%)$ \\
\hline Myocardial infarction on admission & $4 / 100(4 \%)$ \\
\hline Left ventricular ejection fraction [\%] & $52.9 \pm 9.8 \%$ \\
\hline Systolic blood pressure on admission $[\mathrm{mmHg}]$ & $133.5 \pm 13.4$ \\
\hline Diastolic blood pressure on admission $[\mathrm{mmHg}]$ & $79.2 \pm 9.9$ \\
\hline Heart rate $[n /$ min] & $67.9 \pm 8.8$ \\
\hline Body mass index (BMI) $\left[\mathrm{kg} / \mathrm{m}^{2}\right]$ & $28.4 \pm 4.5$ \\
\hline Haemoglobin concentration on admission & $13.9 \pm 1.3$ \\
\hline Platelet count on admission $[\mathrm{n} / \mathrm{ml}]$ & \\
\hline Creatinine concentration on admission $[\mu \mathrm{mol} / \mathrm{l}]$ & $87.2 \pm 20.0$ \\
\hline
\end{tabular}

heparin used during percutaneous coronary intervention was 7600 IU (SD 1900 IU).

\section{In-hospital follow-up (during index}

hospitalization)

The mean time of hospitalization of patients included in the study was 2.5 days (SD 3.4). Two PCI procedures

Table 3. Localization of the treated lesions

Tabela 3. Umiejscowienie leczonych zmian

\begin{tabular}{llc}
\multicolumn{2}{l}{ Localization of the treated lesion } & Percentage \\
\hline One lesion & LAD & 45 \\
\cline { 2 - 3 } & RCA & 19 \\
\cline { 2 - 3 } & Cx & 20 \\
\cline { 2 - 3 } & other & 6 \\
\hline Two lesions & & 10
\end{tabular}

Two lesions

Table 4. Results of visual assessment of the treated lesions

Tabela 4. Wyniki oceny wizualnej leczonych zmian

\begin{tabular}{|c|c|c|}
\hline \multicolumn{2}{|l|}{ Variable } & \multirow{2}{*}{$\frac{\text { Number of lesions }}{106}$} \\
\hline Type of the treated lesion & Native vessel & \\
\hline & Restenosis & 2 \\
\hline \multirow[t]{2}{*}{ Atherosclerotic plaque } & Concentric & 53 \\
\hline & Eccentric & 44 \\
\hline \multirow[t]{3}{*}{ Calcifications } & None & 62 \\
\hline & Moderate & 29 \\
\hline & Severe & 2 \\
\hline \multirow[t]{2}{*}{ Ostial lesion } & No & 95 \\
\hline & Yes & 10 \\
\hline \multirow[t]{2}{*}{ Thrombus } & No & 93 \\
\hline & Yes & 1 \\
\hline \multirow{2}{*}{$\begin{array}{l}\text { Other stenosis }>50 \% \\
\text { in the treated vessel }\end{array}$} & No & 93 \\
\hline & Yes & 8 \\
\hline \multirow[t]{3}{*}{ Lesion length [mm] } & $<10$ & 14 \\
\hline & $10-20$ & 64 \\
\hline & $>20$ & 25 \\
\hline TIMI & $\begin{array}{l}\text { Before } \\
\text { the procedure }\end{array}$ & $\begin{array}{l}\text { After } \\
\text { the procedure }\end{array}$ \\
\hline 0 & 0 lesions & 0 lesions \\
\hline 1 & 7 lesions & 0 lesions \\
\hline 2 & 9 lesions & 0 lesions \\
\hline 3 & 83 lesions & 101 lesions \\
\hline QCA - per investigator & $\begin{array}{l}\text { Before } \\
\text { the procedure }\end{array}$ & $\begin{array}{l}\text { After } \\
\text { the procedure }\end{array}$ \\
\hline Lesion length [mm] & $16.47 \pm 7.10$ & $16.27 \pm 7.61$ \\
\hline $\begin{array}{l}\text { MLD of the stented } \\
\text { lesion }[\mathrm{mm}]\end{array}$ & $1.07 \pm 0.51$ & $3.12 \pm 0.54$ \\
\hline$\%$ DS & $81 \pm 12$ & $7 \pm 11$ \\
\hline
\end{tabular}


Table 5. Adverse events during index hospitalization

Tabela 5. Zdarzenia niepożądane $w$ trakcie pierwszej hospitalizacji

\begin{tabular}{lc} 
Adverse events during hospitalization & Number of patients \\
\hline Death & 0 \\
\hline Myocardial infarction & $2(2 \%)$ \\
\hline Recurrence of angina & 0 \\
\hline Repeated elective PCI & 0 \\
\hline Stroke & 0 \\
\hline Pulmonary embolism & 0 \\
\hline Complications of the access site & $3(3 \%)$ \\
\hline Bleeding (requiring blood transfusion) & 0 \\
\hline MACE & $2(2 \%)$
\end{tabular}

during index hospitalization were complicated by a branch occlusion with a consequent myocardial infarction. Three patients suffered from a haematoma of the puncture site which did not require surgery or blood transfusion. There were 3 cases of distal dissection (type B, C and D) reported during $\mathrm{PCl}$ procedures. No other adverse events were reported (Table 5).

\section{Long-term follow-up of patients}

During 1-month follow-up one patient underwent repeated $\mathrm{PCI}$ procedure of the previously untreated vessel (next step of coronary revascularization).

During 3 months follow-up ( $1^{\text {st }}-3^{\text {rd }}$ month) one patient discontinued clopidogrel treatment due to gastro-intestinal tract bleeding. He was admitted to the general surgery ward, diagnosed with an abdominal tumour and qualified for the surgical procedure - hemicolectomy. One patient underwent repeated $\mathrm{PCl}$ of the previously untreated vessel.

During 6 months follow-up ( $3^{\text {rd }}-6^{\text {th }}$ month) 1 patient died - he was hospitalized and underwent surgery (hemicolectomy) on the surgical ward due to diagnosed gastro-intestinal tumour (a malignant process was found in histopathological examination) and died from multiorgan failure after 2 months of hospitalization. Five patients underwent repeated $\mathrm{PCl}$ of the previously untreated vessels.
During 12 months follow-up ( $6^{\text {th }}-12^{\text {th }}$ month) 2 patients underwent repeated $\mathrm{PCl}$ including one $\mathrm{PCl}$ of the previously treated vessel (TVR). Sixteen patients discontinued thienopyridine treatment 12 months after the procedure as recommended.

Data of patients included in the TAXCOR PL study in various periods of follow-up are presented in Figure 1. Summary of adverse events during 1-year follow-up is presented in Table 6.

\section{Analysis of study end-points}

The primary end-point of the study defined by the study protocol was a TVF. According to the definition this complication occurred in 3 patients (coronary death - 0 , myocardial infarction [STEMI, NSTEMI] - 2, target vessel revascularization [repeated $\mathrm{PCl}$ or surgery with bypasses of the previously treated vessel] during 12 months followup - 1).

The frequency of secondary end-points is presented in Table 7.

\section{Discussion}

Results of the study procedure, in-hospital follow-up and long-term follow-up of patients who underwent implantation of the Genius Taxcor I stent show high safety and efficacy of this method of treatment in patients with ischaemic heart disease as demonstrated during 6-month follow-up.

The presented results undoubtedly show that the use of the Genius Taxcor I stent was safe in a large proportion of patients and led to perfect long-term results of clinical follow-up. Achievement of $98 \%$ success of the studied device and $96 \%$ of the successful procedures is comparable with the results of other registries on drugeluting stents.

Similarly, the frequency of MACE in 1-year follow-up is comparable with that reported in other registries on the efficacy and safety of DES [5], such as the one presented in the study on 2633 patients with implanted DES published in the CCl journal by Ran Kornowski's group, who reported a 3\% frequency of death and over $4 \%$ frequency of TVR during 1-year follow-up. Frequency of the same adverse events in the Taxcor PL registry did

Table 6. Adverse events after 1 year follow-up (FU)

Tabela 6. Zdarzenia niepożądane $w$ rocznej obserwacji

\begin{tabular}{lccccc} 
& Index -1 month FU & 1-3 months FU & 3-6 months FU & 6-12 months FU \\
\hline Death & 0 & 0 & $1(1908)$ & 0 \\
\hline Bleeding & 0 & $1(1908)$ & 0 & 0 & 1 \\
\hline Surgery & 0 & $1(1908)$ & 0 & 0 & 1 \\
\hline Re-PCl & $1(1304)$ & $1(1309)$ & $4(1101,1304,1404,1409)$ & $2(1303,1404)$ & 2 \\
\hline SUM & 1 & 3 & 5 & 1
\end{tabular}


Table 7. Secondary end-points - frequency

Tabela 7. Częstość występowania wtórnych punktów końcowych

\begin{tabular}{|c|c|c|}
\hline End-point & & $\begin{array}{l}\text { Number } \\
\text { of cases }\end{array}$ \\
\hline \multirow[t]{2}{*}{ MACE } & During 30 days follow-up & 2 \\
\hline & During 12 months follow-up & 4 \\
\hline \multirow[t]{2}{*}{ Death } & During 30 days follow-up & 0 \\
\hline & During 12 months follow-up & 1 \\
\hline \multirow{2}{*}{$\begin{array}{l}\text { Coronary } \\
\text { death }\end{array}$} & During 30 days follow-up & 0 \\
\hline & During 12 months follow-up & 0 \\
\hline \multirow{2}{*}{$\begin{array}{l}\text { Myocardial } \\
\text { infarction }\end{array}$} & During 30 days follow-up & 2 \\
\hline & During 12 months follow-up & 2 \\
\hline \multirow{2}{*}{$\begin{array}{l}\text { Target lesion } \\
\text { revascularization (TLR) }\end{array}$} & During 30 days follow-up & 0 \\
\hline & During 12 months follow-up & 1 \\
\hline \multirow{2}{*}{$\begin{array}{l}\text { Target vessel } \\
\text { revascularization (TVR) }\end{array}$} & During 30 days follow-up & 0 \\
\hline & During 12 months follow-up & 1 \\
\hline \multirow[t]{2}{*}{ In-stent thrombosis } & During 30 days follow-up & 0 \\
\hline & During 12 months follow-up & 0 \\
\hline $\begin{array}{l}\text { Success of the studied } \\
\text { device }\end{array}$ & $\begin{array}{l}\text { Defined as final vessel diameter } \\
\text { at stenosis }<30 \%\end{array}$ & $98 \%$ \\
\hline Successful procedure & $\begin{array}{l}\text { Defined as final vessel diameter } \\
\text { at stenosis }<30 \% \text { without MACE } \\
\text { related to the primary lesion } \\
\text { until discharge }\end{array}$ & $96 \%$ \\
\hline
\end{tabular}

not exceed 2\% [6]. Analysis of the frequency of in-stent thrombosis reported in the published studies ranging between one and several percent in 1-year follow-up [7] shows that the studied stent is characterized by a comparable safety profile regarding this complication.

Currently reported data on efficacy and safety of the 'limus' coated stents (such as everolimus) and publications comparing the efficacy of paclitaxel with this new group of drugs show the advantage of the 'limus' group concerning mainly the reduction of major adverse events or target vessel failure requiring repeated interventions [8]. Analysis of the obtained results demonstrates that the frequency of end-points in which 'limus' stents show an advantage over paclitaxel coated stents presented in the Taxcor PL registry is similar to the one reported for the everolimus coated stents.

There are some limitations of the Taxcor PL study including the lack of angiographic assessment of the results by an independent core laboratory, the observational character of the study and the lack of angiographic control or full monitoring of the reported data.

\section{Conclusions}

The results of the Taxcor PL registry demonstrate that the Genius Taxcor I stent is safe in use and leads to satisfactory results in the short-term and long-term follow-

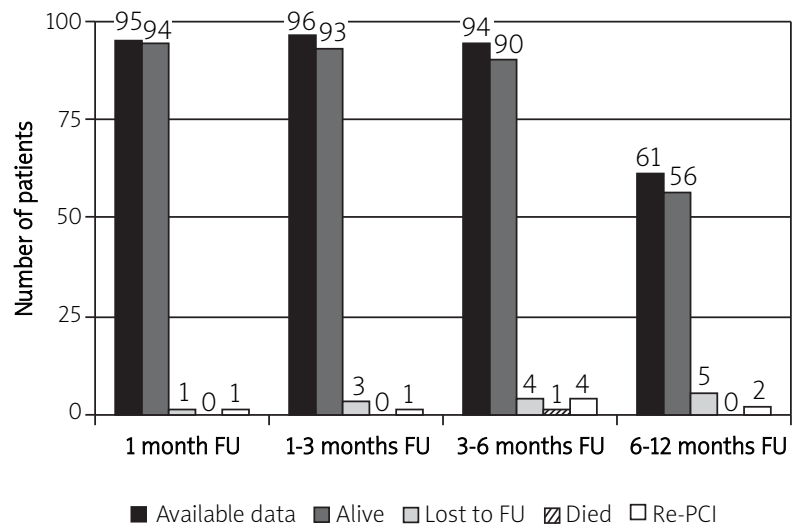

Fig. 1. Summary of FU

Ryc. 1. Podsumowanie FU

up, which is comparable to other commercially available coronary stenting systems.

\section{References}

1. Alexopoulos D, Xanthopoulou I, Karantalis V, et al. Simultaneous drug-eluting and bare-metal stent implantation: long-term clinical outcome and findings of clinically indicated coronary angiography. Clin Cardiol 2011; 34: 317-321.

2. Flores-Ríos X, Abugattás-de Torres JP, Campo-Pérez R, et al. Effect of stent thrombosis on the risk-benefit balance of drug-eluting stents and bare metal stents. Rev Esp Cardiol 2010; 63: 528-535.

3. Stone GW, Ellis SG, Colombo A, et al. Long-term safety and efficacy of paclitaxel-eluting stents final 5-year analysis from the TAXUS clinical trial program. JACC Cardiovasc Interv 2011; 4: 530-542.

4. Kandzari DE, Mauri L, Popma JJ, et al. Late-term clinical outcomes with zotarolimus- and sirolimus-eluting stents 5-year follow-up of the ENDEAVOR III. JACC Cardiovasc Interv 2011; 4: 543-550.

5. Tentzeris I, Jarai R, Farhan S, et al. Long-term outcome after drugeluting stent implantation in comparison with bare metal stents: a single centre experience. Clin Res Cardiol 2011; 100: 191-200.

6. Bental T, Assali A, Vaknin-Assa H, et al. A comparative analysis of major clinical outcomes using drug-eluting stents versus baremetal stents in a large consecutive patient cohort. Catheter Cardiovascr Interv 2010; 76: 374-380.

7. Urban P, Abizaid A, Banning A, et al. Stent thrombosis and bleeding complications after implantation of sirolimus-eluting coronary stents in an unselected worldwide population. J Am Coll Cardiol 2011; 57: No. 13.

8. Stone GW, Midei M, Newman W, et al.; SPIRIT III Investigators. Randomized comparison of everolimus-eluting and paclitaxeleluting stents: two-year clinical follow-up from the Clinical Evaluation of the Xience V Everolimus Eluting Coronary Stent System in the Treatment of Patients with de novo Native Coronary Artery Lesions (SPIRIT) III trial. Circulation 2009; 119: 680-686. 